\title{
Islamic Law, Adat and State Law Franz von Benda-Beckmann on Systems of Property and Inher- itance in Minangkabau
}

\author{
Novelia Musda \\ Work at the Ministry of Religious Affairs at the Municipal of \\ Padangpanjang, West Sumatra. \\ Email:mudah_sadar@yahoo.co.id
}

\begin{abstract}
Franz von Benda-Beckmann is a famous figure in the field of legal pluralism. He is one among scholars who propose to understand the plurality of norms in a society. Among his many works, those on Minangkabau are well-known in the study of Anthropology of Law

(Rechtsethnologie). This article attempts to analyse his ideas in a book entitled Property in Social Continuity: Continuity and Change in the Maintenance of Property Relationships through Time in Minangkabau, West Sumatra published in 1979. It has its relevance in the seminar Anthropology of Islamic Law, especially when the book talked about the pluralistic situation of laws in Minangkabau on problems of property and inheritance. Because the book is predominantly about Minangkabau adat, the author focuses on adat's relation with Islamic law and more specifically on the problem of inheritance which has been a source of much "competition" between both systems to regulate the society.

Keyword: Islamic law, adat, Minangkabau, anthropology, legal pluralism
\end{abstract}

\begin{abstract}
ABSTRAK
Franz von Benda-Beckmann adalah sosok ternama di bidang pluralism hukum. la adalah satu diantara sarjana yang berupaya memahami pluralitas norma dalam masyarakat. Di antara sekian banyak karyanya, kajian tentang Minangkabaulah yang paling terkenal dalam studi Antropologi Hukum (Rechtsethnologie). Tulisan ini menganalisis gagasan-gagasan yang tercermin dalam karyanya yang berjudul Property in Social Continuity: Continuity and Change in the Maintenance of Property Relationships through Time in Minangkabau, West Sumatra yang diterbitkan pada tahun 1979. Karya ini memiliki keselarasan dengan perkuliahan antropologi hukum Islam, khususnya ketika karya tersebut berbicara tentang situasi hukum yang beragam di Minangkabau, khususnya mengenai harta benda dan waris. Karena buku ini lebih banyak berbicara tentang adat Minangkabau, penulis memfokuskan pada hubungan adat dengan hukum Islam, khususnya perihal hukum waris yang menjadi sumber "kompetisi" antara hukum Islam dan hukum adat di dalam mengatur masyarakat.

Kata kunci: Hukum Islam, hukum adat, Minangkabau, antropologi, pluralism hukum
\end{abstract}

\section{INTRODUCTION: ABOUT FRANZ VON BENDA- BECIKMANN}

Franz von Benda-Beckmann is a German scholar now a honorary professor for Legal Pluralism at the University of Halle and for Ethnology at the University of Leipzig since 2004. He is also joint Head of Project Group Legal Pluralism at the Max Planck Institute for Social Anthropology, Halle. He studied in Gymnasium in 
Kiel (1952-1961), became a law student in three universities (Munich, Lausanne and Kiel) from 1962 until 1967. He ever taught law and ethnology in the University of Zurich (1972-1977 and then 1980-1986), the University of Leiden (1978-1981), and was appointed as professor for Law in Developing Countries at Wageningen Agricultural University for about two decades (1981-2000). His field experiences were in Zambia and Malawi (1967-1968), West Sumatra (Minangkabau) (1974-1975 and 1999-2000), Ambon, Moluccas (1985-1986) and also India and Nepal. He is married to another famous scholar of the same interest, Keebet von Benda-Beckmann. Together they have written many books and articles in more or less the same focus.

Franz von Benda-Beckmann is a prolific writer. His works are mainly about the concept of legal pluralism and the phenomenon of plurality of laws in certain societies. The book which I want to study in this paper is of that kind. Among his other works are: Gesellschaftliche Wirkung von Recht: rechtsethnologische Perspektiven (2007); Changing Properties of Property (2006); State, Religion and Legal Pluralism: Changing Constellations in West Sumatra (Minangkabau) and Comparative Issues (paper, 2001); Recreating the Nagari: Decentralisation in West Sumatra (2001); Text in Context: Historical Documents as Political Commodity on Islamic Ambon (1994); Property, Politics and Conflict: Ambon and Minangkabau Compared (1991); Op Zoek naar het Kleinere Euvel in de Jungle van het Rechtspluralisme (1983); Rechtsantropologie in Nederland (1981). ${ }^{1}$

\section{INTRODUCTION TO PROPERTY IN SO- CIAL CONTINUITY Why Minangkabau?}

Minangkabau is the name for the people, the place and the language of the fourth largest tribe in Indonesia. They inhabit nowadays West Sumatra province and parts of Riau, Bengkulu, Jambi, Aceh and the State of Negeri Sembilan in Malaysia. The geography, the adat of Minangkabau and the history of Islam in this place are studied by a great number of scholars, especially since the Dutch occupation. Franz von BendaBeckmann is one among them. He hoped to contribute to the anthropological study of property, inheritance and law in this monograph. He chose Minangkabau because it seems to him that this region is challenging for conducting research in the field, out of at least three reasons: pluralistic situation, variety of institutions dealing with property relationships and contemporary changes (legal and practical) in those matters. He explicitly said that to analyse the situation, he needs to attempt an approach different from that which was usually used by legal anthropologists. Minangkabau is interesting for him also because historical documents on its legal pluralism are relatively well-documented. ${ }^{2}$

\section{AIM OF THE STUDY}

The author's aim in this monograph is to contribute to the ethnographic knowledge of Minangkabau as well as to the antropological study of property, inheritance and law. ${ }^{3}$ Thus, we can understand that he has both particular and general aims in his research. It is particular because it is related to a certain society (Minangkabau) and general because it wants to give some ideas about legal anthropology, especially legal pluralism. There are three focuses listed by Franz von Bendabeckmann upon which he conducted his research with his wife, Keebet: the socio- 
political organization of a nagari; secondly, the processes of dispute-settlement in the nagari institutions and the State Courts supposed to apply substantive adat law but adjusted to procedures of State Law; and the last, the system of property and relationship in Minangkabau. The author said, it is the third focus which is the main focus in this monograph. However, we can see that the other two focuses are also detailly discussed by him in it. The choice to study a particular nagari in Minangkabau, that is nagari Canduang Koto Laweh (CKL) was made because they came to know that the greatest number of disputes they found in the State Court related to the focus of this monograph were from this particular nagari. ${ }^{4}$

\section{METHODOLOGY}

The combination of fieldwork and library research enabled Franz von Benda-Beckmann to make his analysis in this study thoroughand wide-going. Data used in this monograph were taken from reading materials and results of field work conducted by the author and his wife. The reading material is drawn from earlier sources. ${ }^{5}$ Franz von BendaBeckmann also studied Dutch sources on Minangkabau in libraries in the Netherlands intensively before visiting West Sumatra. While in the field work, they interviewed judges and staff-members of State Courts in the districts of Agam, 50 Kota and Tanah Datar and also checked registers and analysed court records. ${ }^{6}$ The author also consulted adat experts and talked with common villagers in various ways to get understanding of the Minangkabau adat and its actual practices. ${ }^{7}$

\section{THEORETICAL FRAMEWORK}

We can find the theoretical framework in this monograph mainly in the first chapter and conclusion and also in parts of other chapters. Franz von Benda-Beckmann firstly means by society as not only a composite of individuals, but it also has inclusive social formations with group-character. Borrowing from Moore, he labeled these social formations "semi-autonomous" groups in the sense that they represent an entity in which the autonomy of the members is restricted and recognized, but the autonomy of the group itself is also restricted in relation to the other groups. ${ }^{8}$ He then listed four criteria to asses various forms of the restriction and the recognition. ${ }^{9}$ Firstly, the degree of institutionalization, that is to what degree the members are free to build their own or new conceptions. Secondly, the referent of institutionalization; whether it refers to procedural conceptions or substantive content. Franz von Benda-Beckmann said that in many traditional societies, it is the former that mainly restricts the autonomy of the members, whereas in many western societies, the case is otherwise. Thirdly, the complexity of institutionalization; here, the author mentions diachronic and synchronic patterns as two kinds of the arrangement of institutional requisites consisting of a diversity of institutions. ${ }^{10}$ By diachronic he understands that we must go through several institutional steps to deal with certain problem, e.g. in marriage. By synchronic he means that we can choose among several alternatives, e.g. in many African societies, one can choose marriage by elopement or in court. Then, the last criterium to evaluate the restriction of the autonomy of a society's members is the what he called "mandatoriness of institutionalization"; whether the conceptions through which social organization is expressed are prescrip- 
tive, facultative, optional or only options. ${ }^{11}$

Concerning the concept of law, Franz von Benda-Beckmann differentiated three approaches used by anthropologists to define law. ${ }^{12}$ In the first approach, they can consider law as a domain of social organization; thus, law is treated as social process. This trend is applied by the followers of the case-methods. Gulliver and Hoebel are included by him in this party. For the followers of the second approach, among them Maine, Durkheim and Fried, law is related to forms of normative conceptions particular to a specific form of political organization. It proposes that "law" developed from "custom" and "state" from kinship-based communities. The third approach is to treat law as a dimension of social organization inherent in all social institutions. Law is seen as related to all domains of social life and can be separated from the social processes. Franz von BendaBeckmann said that he used this approach in this monograph because, for him, it has great analytical and heuristic values for the anthropological study of law. ${ }^{13}$ Other representatives of this approach are Vinogradoff,

Malinowski, Gluckman and Moore.

Further elaborating the concept of law used in this study, Franz von BendaBeckmann stated that law comprises both cognitive and normative conceptions; in his own words," Law is not only concerned with the consequences following from certain situation-images, but it also contains conceptions determining the facts from which the consequences follow." 14 There are three standards to evaluate situation-images for legal relevance: permissibility, validity and an indifferent standard. ${ }^{15}$ Two manifestations of law are also mentioned by him: general law and concrete law (the law for "cases"). The first evaluates typified situation-images for their consequences, while concrete law evaluates a concrete situation-image for its concrete consequences. ${ }^{16}$

About the property relationships, the author of the monograph said that its social organization is manifested in both general and concrete legal conceptions. He indicated two levels on which the relationships are expressed: the level of socio-political authority and the level of use and exploitation. This distinction is really useful in studying Minangkabau system of property. However, he concedes that it is not new, since Leach, Llyod and Vanderlinden have spoken about some aspects of it. ${ }^{17}$

The problem of inheritance is considered to be the problem of maintaining the system of property relationships through time. ${ }^{18}$ It signifies the transfer of rights and obligations of the deceased to the heirs and it happens in and through law. ${ }^{19}$ Franz von BendaBeckmann distinguishes between diachronic and synchronic transfers. Diachronic transfer has to do with inheritance which is through time, while the other with property law in general between the living within the same time. ${ }^{20}$ In relation to individual freedom in property affairs: the more diachronic thinking dominates the less individuality and individual freedom is appraised. The greater the freedom is recognized, the more will continuity decrease in importance, as is the case in contemporary western legal systems. ${ }^{21}$ As we can also see further in this monograph, property relationships in contemporary Minangkabau increasingly give more space to individual freedom.

\section{STRUCTURE OF THE MONOGRAPH}

The book with 455 pages consists of seven 
chapters, introduction, notes, glossaries, bibliography and maps. Chapter I is entitled "Basic Assumptions and Hypotheses" and deals with conceptions about social institutions, social functions and concepts of law. In this chapter, F.v. Benda-Beckmann explains views of other scholars on these themes and then proposes his own opinions. It is also interesting to study his views on the definition of law by his summarizing three approaches to define law and why he prefers the third for his own analysis, especially that which is used in the book. ${ }^{22}$ Some ideas about "legal pluralism" can be seen in this difficult chapter. In Chapter II, he is more specifically concerned with Minangkabau. Franz von Benda-Beckmann delves into explaining socio-political organization in Minangkabau, group formations, local terminologies like nagari, buah gadang and jurai and also authority vested in each group. The author does not forget to talk about marriage as a kind of relationship among groups and also types of residence known in Minangkabau traditional society.

Pluralistic situation of law or legal systems in Minangkabau of the past and the present is the core of the Chapter III. By pluralistic he means the existence of adat law, Islamic law and written law which together deal with the problems of property and inheritance. Each of the systems has its own unique history and their mutual interaction is always attractive to study. Systems of property relationships in Minangkabau illuminated by the approach to pluralistic situations are elaborated in Chapter IV. Benda-Beckmann explains the definition of terms for kinds of property relationship used in adat (e.g. pagang, gadai, harato pusako) and Islamic law (e.g. milk, hibah, farâidh) and proceeds to give light to the introduction of written law, firstly by the Dutch in the colonial period and then by the Indonesian government after independence . Chapter V and VI are about the application of the systems in the reality of the Minangkabau society. The former gives us stories of affairs in property relationships and inherintance in Minangkabau society and the latter analyses the legal conceptions in Minangkabau with changes from time to time. It must be of special interest for me to study the clash between adat and Islamic law included in the sixth chapter. Chapter VII is conclusion. In this last chapter he considers factors of change in the relationships of property and inheritance through time in Minangkabau. It illuminates us in seeing how in the present Minangkabau adat's influence upon Minangkabau people has decreased, not only apprehended by outsiders but also felt by concerned Minangkabauers. Notwithstanding, the conceptions of adat itself on property relationships do not significantly change.

\section{ORGANIZATION OF MINANGKABAU SOCIETY}

As mentioned earlier, one of the aims of this monograph is to present some ethnographic knowledge of Minangkabau, especially in relation to the system of property according to adat and its practice in society. The second chapter is devoted to give ample explanation about the socio-political organization in Minangkabau. However, historical development is not given enough description. The author seems to focus on the present (i.e. in his time) situation. Since the author is fully aware that there are sometimes differences in terminology among many nagari in Minangkabau concerning groups, territorial division of nagari and other conceptions, he 
always indicated that when he observed particulary those he knew in nagari Canduang Koto Laweh.

In order to understand the situation in Minangkabau, one must be first fully aware that fundamental socio-political units are structured according to the conception of matrilineal descent defined as blood relationship (batali darah). ${ }^{23}$ However, it is not the only one, other inter-individual relationships established for example through marriage and political arrangements are also important. $^{24}$

Fundamental constituent unit in group formation in Minangkabau is called paruik, buah paruik, kaum or buah gadang, according to terminology used in particular nagari. ${ }^{25}$ Buah gadang is defined as "one" in term of having one panghulu-title or one panghulu (sasako or sapanghulu), one-heritage (sapusako) and one-property (saharato). ${ }^{26}$ It consists not only of persons having common matrilineal descent from one apical female ancestor, but also of strangers and descendants of former slaves given nagari "citizenship". The latter two need to be associated with or incorporated in a certain buah gadang in order to acquire that "citizenship". However, they assume inferior status in the buah gadang in terms of rights, especially to harato pusako. ${ }^{27}$ Buah gadang is also divided into kaum; the latter is a potential sub-unit of the buah gadang. There is also another term for denoting sub-unit of the buah gadang: jurai. Nevertheless, jurai can be more specific in that it can mean only a mother and her children ${ }^{28}$, but also general in that it can be identical with kaum. ${ }^{29}$ As stated by Franz von BendaBeckmann, the number of the sub-units in particular buah gadang vary among all buah gadang in the nagari. ${ }^{30}$ There are buah gadang having $13 \mathrm{kaum}$, and there are others that consist of only one kaum, the average being three or four.

On the levels higher than buah gadang, one has to deal with suku and nagari. These all are constituted in Minangkabau adat. It is stipulated that a nagari must consist at least of four suku. The relation between suku and buah gadang itself is like that of unit and its sub-unit. The association of some or many buah gadang into a suku is not really based on actual common matrilineal descent, but may be on "administrative" function. Thus, suku has group character only on the nagari level. ${ }^{31}$ However, a Minangkabaunese states that he belongs to this or that suku when he identifies himself also on supra-nagari level, for example when he is asked from which nagari he comes and from which suku if the person who asks happens to be interested in identifying him more. Nagari is thus a socio-political organization in Minangkabau consisting of at least four suku and this in turn of some or many buah gadang. For example, nagari Canduang Koto Laweh at its founding time is said to consist of 7 suku and 60 buah gadang. ${ }^{32}$

The description above is the basic description of literatures on Minangkabau society. However, in dealing with the residence rules in Minangkabau, Franz von BendaBeckmann's description differs from others in categorizing three aspects of residence: domestic, economic and political. ${ }^{33}$ Of the three, he said the last is not given enough attention by other scholars. He describes the political residence in Minangkabau as matrilocal, distinguishing between residence in adat, in buek, in pusako and in jorong. To conclude, he said that for a married Minangkabau man, residence is duolocal: his domestic residence is uxorilocal and his 
political residence matrilocal. ${ }^{34}$ The complexity of residence rules in Minangkabau will determine a range of activities a

Minangkabau man, in particular, will do in his life as a buah gadang member, as a husband, as a member of community also.

\section{PLURALISTIC SITUATION IN DEALING WITH PROPERTY RELATIONSHIPS IN MINANGKABAU}

Legal pluralism is a familiar terminology when we deal with works of Franz von BendaBeckmann. He said that he used the term for the first time for the title of his dissertation on legal systems in Malawi, but he was not fully aware of the consequences of such a concept. ${ }^{35}$ One important point that is still now raised in discussions about legal pluralism is that whether one can really speak of "law" and legal pluralism when normative systems like adat and Islamic law are not recognized as law by the State. Anyhow, it is only the perspective of positive jurists, he said further, and not to be taken by social scientists. ${ }^{36}$ Woodman, who defines legal pluralism as "the condition in which a population observes more than one body of law", also said that this term is a concept only used in the social scientific study of law. ${ }^{37}$

In this monograph, Franz von BendaBeckmann doesn't explicitly talk about the concept of legal pluralism itself, except some mentioning of it in few pages, e.g. page 120 and 121 . He only explained the pluralistic situation in Minangkabau in details, in which there are three distinctive legal systems available, i.e. adat/adat $\mathrm{law}^{38}$, Islamic law and written law, which deal with property relationships, transfers of property of synchronic and diachronic characters. Whereas his focus is largely on adat and adat law, his elaboration of the two other systems is really interesting because he explains the interaction between the three systems with examples of court cases and gives light to the change upon and within Minangkabau adat through time, as the title of the book suggests.

The brief history of the existence and the actual use of the legal systems is given. Before the coming of Islam in Minangkabau, even before Paderi war, its adat is not sufficiently known to us due to lack of data. Islam indeed brought different ways of thinking about property and property relationships. Its faraidh (law of inheritance) was understandbly considered a challenge to adat conception of inheritance. However, Islamic terminologies like warih (waris), hibah, wasiyat, ulayat, hak and milik and adat itself were incorporated into vital adat concepts but with different meanings. It makes the assessment of preIslamic adat conception much more difficult. And since Minangkabau adat is manifested in many metaphorical proverbs and sayings with a poetic character used mainly to express and transmit various standards and guidelines for their everyday behaviour in social life, ${ }^{39}$ it is not easy to determine which proverbs from pre-Islamic period even if the expressed words contain no Arabic loans. Only with the coming of the Dutch and their occupation of the heart land of Minangkabau did begin a clear picture of Minangkabau adat come to light, especially for outsiders. The Dutch had interest in studying it for practical or administrative and scholarly purposes.

Concerning the system of property in adat (adat pusako), the author deals with the category of property, its acquisition, its use and transfers of property relationships. Material property object is called harato in Minangkabau (Indonesian: harta). They can 
be divided into two kinds: harato pusako (pusako property) and harato pancaharian (selfacquired property). ${ }^{40}$ Most harato pusako is land and harato pancaharian is mainly in the form of movable property objects; but, the latter also includes land having been bought (by one's own money for example) or cultivated for the first time. ${ }^{41}$ If Minangkabau man and woman marry, the total of the couple's harato pancaharian is called harato suarang. However, each of them usually "brings" with them some harato before marriage, for man this brought harato is called harato pambaoan (brought property), for woman harato dapatan (received property).

The property each brings into marriage may consist of both harato pusako and harato pancaharian, but in most cases it is harato pusako (of his or her kaum). ${ }^{42}$

The harato pancarian and harato pusako are not to be totally separated because the former can be converted into the latter (not otherwise). This is what Franz von BendaBeckmann call pusakoization of harato pancaharian. The mechanism is that after the death of the holder of harato pancaharian his or her heirs will inherit it. The heirs are not really individuals, but group, i.e. his jurai or buah gadang. So, it will be treated as pusako, as increasing pusako of the person's buah gadang. The author explores its legal impacts and the problems resulting from this concept in adat, taking attention to the fact that in the present time (in the time he did research until now) this has changed considerably. I will discuss it later in this paper.

One of the most striking manifestations of matrilineality in Minangkabau is adat rule concerning who will be the heirs of the deceased. The distribution of a kaum's harato pusako is conducted in three ways: ganggam bauntuak, harato dapatan and harato pambaoan. ${ }^{43}$ Ganggam bauntuak (literally means: "a handful to be duely divided for use") in principle can be understood as the way in which pusako property is "given" to the woman and her jurai to be used and explored for their own needs. The "woman" can be grandmother, mother, sister or grandsister in matrilineal descent, especially those who have family or children. In other words, females are the holders of ganggam bauntuak. Ideally, it is not evenly given, for the most in need will be given greater part. ${ }^{44}$ The allocation is accomplished in a musyawarah (family meeting) in which the mamak (the leader of the jurai, usually the oldest male in the jurai) plays a significant role in leading the meeting and preparing the mufakat (unanimous decision). The important aspect in distribution of harato pusako is that it remains the property of the kaum. It is divided only for use. ${ }^{45}$ It is the strength of the rules concerning harato pusako in that it will lead to the benefits of all members of the kaum in continuity; if it is converted to own's own property, the owner will tend to use, sell or pawn it as so much as he likes that next generations will not take benefit of it anymore. ${ }^{46}$ Concerning harato dapatan and harato pambaoan, very brief explanation in previous page is enough in this occasion.

To transfer harato pusako, there are some mechanisms known in Minangkabau adat: selling and buying, pawning (gadai with several forms), privileged loan (sando and others); while for harato pancaharian, in addition to the three mechanisms, there are gift in several forms (hibah, umanaik, wasiyat, pemberian), and utang (debts). These mechanisms are exactly what have changed in the course of time, for example in relation to the 
degree of the freedom in disposing harato pancarian. It will be dealt later.

Islamic law contributes to Minangkabau adat not only in providing new terminologies, but also some forms of transfer of harato not known before, such as hibah and wasiyat. In fact, both are purely new institutions brought by Islam to be incorporated in Minangkabau adat. ${ }^{47}$ We may consider another kind of transfer introduced by Islam: waqf. Rules of pawning and methods of selling and buying are also influenced by Islamic law to a certain extent. As already known, adat rules concerning who will be the heirs of property of the deceased are different from those in Islam. In adat, men are not given ganggam bauntuak, but they will be given the right to use and exploit harato pusako of their kaum and also control or supervise the allocation of it if they become mamak in their jurai.

It is interesting to note that rules of hibah in Islam are also understood differently by Minangkabau people in certain forms of hibah and certain aspects of it. The author gives satisfying explanation of the matter, at least to make us understand how Islamic law gets different meaning for the people. Hibah in adat can be hibah of harato pusako and harato pancaharian. Hibah of harato pusako usually means the transfer of harato pusako of the jurai of a father to his children. This kind of hibah is not indefinite, because it is only for their life-time or their jurai's (until their jurai extinct). If they die, so the harato pusako will be back to their father's jurai. ${ }^{48}$ A common form of hibah of harato pancaharian is hibah from his father to his children. The father employs this mechanism because in adat his children will not inherit their father's property. Amir Syarifuddin also ascribed it to the growing consciousness of the Minangkabau father to be responsible materially and morally to his family. ${ }^{49}$ While hibah in Islam is valid in the lifetime of the giver, principally irrevocable and as much as the donor will give, ${ }^{50}$ in Minangkabau adat, hibah of harato pancaharian is only valid after the death of the donor, revocable and must occur with the "knowledge", even consent of the father's jurai or ahli waris. However, from time to time (explained by the words "change" and "continuity", the freedom to dispose harato pancaharian by Minangkabau men has significantly increased.$^{51}$ Hibah as known in Islamic law, however, may occur in other cases in the sense that it is a kind of ordinary gift or donation.

One element of the plurality of legal systems in Minangkabau dealing with property relationships is western law introduced by the Dutch and later adopted by the Indonesian State. The feature of the Western law in Minangkabau is its written form. In the colonial period, there were regulations which affected the system of property relationship in Minangkabau. The first was the decree of 1853 (amended in 1910) concerning the pusako-eigondomsakte. Pusako land in this decree could be given ownership-deed and then became subject to Dutch formal law, ${ }^{52}$ though the substantive law remained that of adat law. In 1870, Agrarian Act (Agrarische Wet) was also introduced to the whole colony and in 1874 there was a special declaration of State Domain in Sumatra. The latter meant that tanah ulayat (a kind of common pusako of a particular nagari) would fall under the State's domain. However, due to its sharp contrast to adat law of Minangkabau, this declaration had very little or no success. ${ }^{53}$ After the independence, the Indonesian State introduced Undang-Undang Pokok 
Agraria (the Basic Agrarian Law) in 1960 which affirmed to be based on adat law but modelled after Western law. Some regulations in the Marriage law of 1974 also regulate marital property law. ${ }^{54}$

Apart from influences in law, many changes in socio-political system and economy have contributed to the system of property relationship. With the weakening of the authority of penghulu and mamak in Minangkabau and loosening of the matrilineal kinship tie within suku, buah gadang and jurai, the holding of distributed pusako property (ganggam bauntuak) tends to be regarded as individualistic and permanent. ${ }^{55}$ The monetarization (the introduction of the use of money) has significantly contributed to the individuation of property relationships and the way they are evaluated.

Franz von Benda-Bergmann argued that despite many influences outside Minangkabau adat, the traditional system can absorb them; in his own words," the notion of pusako continuity is still strong and as yet absorbs an ever expanding present...many factors which on the one hand weaken the pusako system, reinforce it again on the other". 56

One important message brought by the author in this discussion is that this plurality of norms is responsible for both the change and continuity of Minangkabau adat especially in dealing with property relationships. With the coming of Islam which introduced hibah and wasiyyah into adat and with the coming of the Dutch contributing to a new way of thinking about property in Minangkabau people, adat proves itself to be adjusted to new conditions of the time and to articulate its concepts in more relevant ways towards the needs of modernity.
In encountering modern needs, Minangkabau adat is really flexible in that certain development can be accommodated. For example, in his article, Franz von BendaBeckmann doesn't see the reason that registration of pusako land is contrary to adat. ${ }^{57}$ When the villagers don't want to register their land (as demanded by State laws) and use adat to justify their behaviour, it is not due to adat itself, but their own motivations which in turn depend on the contexts of their interaction with state administrative. ${ }^{58}$ Thus, adat can adopt some elements of State laws as it has still done with Islamic law.

\section{AN INTERESTING CASE: HARATO PANCAHARIAN IN MINANGKABAU}

As already known, Islamic law has rules concerning inheritance as stated in the Quran and developed by the 'ulama. Minangkabau adat also has its own rules concerning this matter, which are very different from Islamic prescriptions but maintained by Minangkabau tradition. Franz von Benda-Beckmann ${ }^{59}$ indicated that inheritance has always been a central issue in the struggle of each side to gain supremacy in Minangkabau society. Even before the Paderi war in the beginning of the 19-th century, there was demand to take some attention to Islamic law of inheritance. ${ }^{60}$ Harato pancaharian is indeed the property owned by a person, but the problem lies in who will be the heir if he or she dies. Minangkabau adat with its strong emphasis on the kaum-ness of a person, the person's autonomy in disposing his self-acquired property is restricted to the extent that other people in his kaum should have also be considered to be given some parts of it, especially his kamanakan (if the person is male). One can give certain portion 
of his harato pancaharian to whom he likes (especially his children) only through hibah as we have seem earlier in this paper. Moreover, Minangkabau adat stipulates that harato pancaharian is deemed to be harato pusako once it is inherited in the new owner's jurai ${ }^{61}$. It means that if one's children have received his harato pancaharian, it will in turn be harato pusako in the children's jurai (their mother's kaum). It is also the task of all group member to increase their harato pusako, the most important way of which is via harato pancaharian. ${ }^{62}$ Datuak Sangguno Di Rajo in the beginning of this century even emphasized that if harato pancaharian is acquired with the capital from harato pusako, adat "demands" that one half of it be returned to the kaum in order to increase pusako of the kaum itself..$^{63}$

There were and are always oppositions to this restriction of one' right of his own acquired property. The coming of Islam had give one impetus to nuance the opposition. Franz von Benda-Beckmann stated that Minangkabau merchants and traders in the past insisted that harato pancarian be inherited according to Islamic law. ${ }^{64}$ Besides that of them, opposition of ulama themselves was of great importance in this discourse. One of Minangkabau 'ulama who severely criticized Minangkabau adat system in property relationships was Ahmad Khatib Minangkabawy. He insisted that it is religiously forbidden (harâm) to follow inheritance rules of Minangkabau adat. His central argument is that the rules clearly contradict Islamic teachings as laid in the Quran and Sunnah. ${ }^{65}$ Amir Syarifuddin criticized Ahmad Khatib's conclusion, saying that harato pusako is not to be inherited according to Islamic law (farâidh) because it is not individual property of the heir(s). ${ }^{66}$ Harato pusako is in the hand of the heir only for temporary time and also only for use and exploitation, but it remains the property of the group (kaum) to be inherited to the next generations. Ahmad Khatib in his view did not properly differentiate between the status of harato pusako and that of harato pancaharian.

Efforts to have greater freedom to one' own harato pancaharian have brought many conflicts among Minangkabau people. In the past, "Children and kamanakan conflict" was the most famous form of these conflicts. This was a classical conflict, in which both parties disputed their father's/mamak's harato pancaharian. In the contemporary Minangkabau society, this kind of conflict is much less common. One of the important reason is that in the formal meetings of representatives of adat leaders (penghulu) of Minangkabau, ulama, intellectuals and government administratives first in 1952 and finally in 1968, it was stipulated that harato pancaharian is to be completely separated from harato pusako, and that, it should be inherited according to Islamic law of inheritance (farâidh). ${ }^{67}$ Thus, if the status of the disputed property has been established as harato pancaharian, no childred-kamanakan conflict will emerge. ${ }^{68}$

Changes in socio-political systems and economy since two centuries ago have indeed affected Minangkabau adat. With the influences from Islamic law and Western law, Minangkabau people increasingly speak of hak milik when they refer to harato pancaharian. They insist that their harato pancaharian is their individual (hak) milik, meaning that they have full right to use and dispose it as they want. This view will no doubt lead to abolition of the concept of 
pusakoization of harato pancaharian. If this happens, harato pusako will not increase anymore; it even decreases. Franz von BendaBeckmann maintained that by increasing use of money and continuing individualization of use-rights (ganggam bauntuak) more harato pusako itself will be pencaharianized. ${ }^{69}$ It will pose a serius threat to the concept of adat pusako.

According to adat experts, however, adat itself has not changed. The changes happen within the adat. Minangkabau adat in the past recognized certain freedom of the disposition of one' harato pancaharian..$^{70}$ What has changed in the course of time is the degree of this freedom. In contemporary

Minangkabau, according to the formal meeting of Minangkabau penghulu and ulama in 1968, a Minangkabau man is free to give his harato pancaharian to whom he likes. Franz von Benda-Beckmann seemed to agree with the adat experts. ${ }^{71}$ The change in this matter is understood by him as a systematic development of the old adat which indeed recognized the individual's autonomy of his harato pancaharian and not as a contradiction to it. ${ }^{72}$

\section{CONCLUSION}

Imran Manan briefly discussed ideas brought by Franz von Benda Beckmann in this monograph. ${ }^{73}$ He said Franz von BendaBeckmann argued that most of the changes affecting Minangkabau society since the end of the Paderi War, as he observed, can be integrated into the traditional adat. The matrilineal key values are still maintained to a great extent, especially concerning harato pusako. Anyone who predicts that matrilineal system in Minangkabau would disintegrate doesn't fully understand the flexibility and adaptability of Minangkabau adat.

To conclude, Franz von Benda-Beckmann generally insisted that the changes in property and inheritance systems are in fully accordance with established adat conceptions. The plurality of legal systems in Minangkabau regulating the property relationships did not and does not destroy the adat, but helps to enrich it with more possibilities and opportunities to deal with the challenges brought by the change of the time. Islamic law contributed many things to Minangkabau adat; not only are the contributions in loaning words and key terminologies to denote property relationships and inheritance, new conceptions such as hibah and wasiyat are also integrated into adat system. The monograph is a highly valuable material for me to study my own Minangkabau society and its adat pusako, especially that dealing with the property relationships, and its interaction with Islamic teachings. There are many things which previously escaped my attention. It is a happy opportunity that I am given the task of studying this monograph for the course of Anthropology of Islamic law.

\section{ENDNOTES}

1 I take the curriculum vitae of the author from the website: http://www.eth.mpg.de/dynamicindex.html?http://www.eth.mpg.de/people/fbenda/ project.html

2 Franz von Benda-Beckmann, State, Religion and Legal Pluralism: Changing Constellations in West Sumatra (Minangkabau) and Comparative Issues (19-th Working Paper). (Halle/Saale: Max Planck Institute for Social Anthropology, 2001), p. 8.

3 Franz von Benda-Beckmann, State, Religion and Legal Pluralism, p. 5.

4 Franz von Benda-Beckmann, State, Religion and Legal Pluralism, p. 12.

5 Franz von Benda-Beckmann, State, Religion and Legal Pluralism, p. 8.

6 Franz von Benda-Beckmann, State, Religion and Legal Pluralism, p. 9.

Franz von Benda-Beckmann, State, Religion and Legal 
Pluralism, p. 10.

8 Franz von Benda-Beckmann, State, Religion and Legal Pluralism, p.18.

$9 \quad$ Franz von Benda-Beckmann, State, Religion and Legal Pluralism, p. 22.

10 Franz von Benda-Beckmann, State, Religion and Legal Pluralism, p. 23.

11 Franz von Benda-Beckmann, State, Religion and Legal Pluralism, p.24.

12 Franz von Benda-Beckmann, State, Religion and Legal Pluralism, p.26.

13 Franz von Benda-Beckmann, State, Religion and Legal Pluralism, p. 27.

14 Franz von Benda-Beckmann, State, Religion and Legal Pluralism, p. 28.

15 Franz von Benda-Beckmann, State, Religion and Legal Pluralism, p. 29.

16 Franz von Benda-Beckmann, State, Religion and Legal Pluralism, p.31.

17 Franz von Benda-Beckmann, State, Religion and Legal Pluralism, p. 43.

18 Franz von Benda-Beckmann, State, Religion and Legal Pluralism, p.45

19 Franz von Benda-Beckmann, State, Religion and Legal Pluralism, p. 44.

20 Franz von Benda-Beckmann, State, Religion and Legal Pluralism, p.48.

21 Franz von Benda-Beckmann, State, Religion and Legal Pluralism, p. 49.

22 Franz von Benda-Beckmann, State, Religion and Legal Pluralism, pp. 26-27.

23 Franz von Benda-Beckmann, State, Religion and Legal Pluralism, p. 60.

24 Franz von Benda-Beckmann, State, Religion and Legal Pluralism, p. 61.

25 It is somewhat confusing when we must deal with different terms for one definition, because in this book buah gadang is said to consist of one or more kaum, and paruik is only members of buah gadang of one matrilineal descent; however, since Franz von BendaBeckmann clearly made distinction between these terms, in which nagari it is used (i.e., in CKL) and explicitly stated that in other nagari the terminology may be very different, I will follow him in preferring his definition of buah gadang, kaum, etc, in this paper.

26 It is penghulu in the sense of family leader, not religious official. In Minangkabau, penghulu very rarely or perhaps never refers to religious official as in Java, especially in the past.

27 Franz von Benda-Beckmann, State, Religion and Legal Pluralism, p. 62.

28 Father of the children is not a member of buah gadang or jurai; in Minangkabau, he is of another group, i.e. jurai of his mother.

29 Franz von Benda-Beckmann, State, Religion and Legal
Pluralism, p. 70.

30 Franz von Benda-Beckmann, State, Religion and Legal Pluralism, p. 65.

31 Franz von Benda-Beckmann, State, Religion and Legal Pluralism, p. 72.

32 There are other terms which are applied in the context of grouping or social formations in Minangkabau, such as kampuang, buek, jorong, rumah, pariuak, etc. I will not describe them further to focus only on the most important ones.

33 Franz von Benda-Beckmann, State, Religion and Legal Pluralism, p. 107.

34 Franz von Benda-Beckmann, State, Religion and Legal Pluralism, p. 112.

35 Franz von Benda-Beckmann, "Rechtspluralismus: Analytische Begriffsbildung oder PolitischIdeologisches Programm?" Zeitschrift für Ethnologie, 119, (1994), p. 6.

36 Benda-Beckmann, F.v. and K. v. Benda-Beckmann, Gesellschaftliche Wirkung von Recht: Rechtsethnologische Perspektiven (Berlin: Dietrich Reimer Verlag, 2007), p. 72.

37 B. Dupret \& M. Berger, et al, Legal Pluralism in the Arab World (The Hague: Kluwer Law International, 1999), p. 3.

38 Adat and adat law are seen as different in that the latter is more concerned with judicial system (see p. 117 and 118 of the monograph).

39 Imran Manan, "A Traditional Elite in Continuity and Change: the Chiefs of the Matrilineal Lineages of the Minangkabau of West Sumatra, Indonesia," Dissertation. Michigan: University Microfilms International (1984), 48.

40 Harato pusako is a designation used to denote material property of heritage (pusako) of a group (buah gadang, suku or jurai) in Minangkabau adat. Immaterial pusako is called pusako kebesaran which consists of adat sayings (pepatah-petitih), adat istiadat (customs) and the titles of penghulu (sako) (see in the monograph pp 147). As far as I know, the term harato pusako is also felt as a pride for a Minangkabaunese and symbol of identity in his particular suku or buah gadang.

41 Franz von Benda-Beckmann, State, Religion and Legal Pluralism, p. 149.

42 Franz von Benda-Beckmann, State, Religion and Legal Pluralism, p. 150

43 Note here that the harato pusako mentioned is in kaum level, which is sub-unit of buah gadang and has some jurai as its sub-units.

44 Franz von Benda-Beckmann, State, Religion and Legal Pluralism, p. 155.

45 Dt. Sangguno Dirajo I., Curaian Adat Minangkabau (Bukittinggi: Kristal Multimedia, 2003), p. 185.

46 Dt. Sangguno Dirajo I., Curaian Adat Minangkabau, 187.

47 A. Syarifuddin, Pelaksanaan Hukum Kewarisan Islam 
dalam Lingkungan Adat Minangkabau (Jakarta: Gunung Agung, 1984), p. 175.

48 A. Syarifuddin, Pelaksanaan Hukum Kewarisan Islam," p. 178.

49 A. Syarifuddin, Pelaksanaan Hukum Kewarisan Islam,"p. 254.

50 A. Syarifuddin, Pelaksanaan Hukum Kewarisan Islam," p. 198.

51 The next theme $(E)$ in this paper will specially deal with the problems of harato pancaharian.

52 A. Syarifuddin, Pelaksanaan Hukum Kewarisan Islam," p. 210.

53 A. Syarifuddin, Pelaksanaan Hukum Kewarisan Islam," p.211.

54 A. Syarifuddin, Pelaksanaan Hukum Kewarisan Islam," p. 213.

55 A. Syarifuddin, Pelaksanaan Hukum Kewarisan Islam," p.382.

56 A. Syarifuddin, Pelaksanaan Hukum Kewarisan Islam," p. 383.

57 Franz von Benda-Beckmann, "Scapegoat and Magic Charm: Law in Development Theory and Practice," In Mark Hobart (ed.) An Anthropological Critique of Development: The Growth of Ignorance (London, Routledge, 1993), p. 123.

58 Franz von Benda-Beckmann, "Scapegoat and Magic Charm," 129

59 Franz von Benda-Beckmann, State, Religion and Legal Pluralism, p. 15.

60 Paderi war (early $19^{\text {th }}$ century-1837) was at the beginning a civil war between adat supporters and Islamic reformers before it became a great war between Minangkabau people and the Dutch.

61 It is then named harato pusako randah (literally: low pusako property). Franz von Benda-Beckmann, State, Religion and Legal Pluralism, p. 151.

62 Franz von Benda-Beckmann, State, Religion and Legal Pluralism, p. 151

63 Dt. Sangguno Dirajo I., Curaian Adat Minangkabau, p. 189.

64 Franz von Benda-Beckmann, State, Religion and Legal Pluralism, p. 16.

65 Yasrul Huda, "Islamic Law versus Adat: Debates about Inheritance Law and the Rise of Capitalism in Minangkabau," (MA Thesis). Leiden: University of Leiden, 2003, p. 64.

66 A. Syarifuddin, Pelaksanaan Hukum Kewarisan Islam," p. 277.

67 It is not clear whether in the practice, present Minangkabau people really apply the results of the meeting in their everyday life. As far as I know, it is still not common that the inherited acquired property is inherited according to hukum faraidh. That it is inherited to the children, on the other hand, is very common (especially intestate inheritance, this has become more popular than in previous time). A. Syarifuddin, Pelaksanaan Hukum Kewarisan Islam," p. 265.

68 A. Syarifuddin, Pelaksanaan Hukum Kewarisan Islam," $p$. 265.

69 A. Syarifuddin, Pelaksanaan Hukum Kewarisan Islam," p. 382.

70 A. Syarifuddin, Pelaksanaan Hukum Kewarisan Islam," p. 375.

71 A. Syarifuddin, Pelaksanaan Hukum Kewarisan Islam," p.370.

72 A. Syarifuddin, Pelaksanaan Hukum Kewarisan Islam," p. 372.

73 Imran Manan, "A Traditional Elite in Continuity and Change," 22.

\section{BIBLIOGRAPHY}

Benda-Beckmann, F. v. (1979): Property in Social Continuity: Continuity and Change in the Maintenance of Property Relationships Through Time in Minangkabau, West Sumatra. The Hague: Martinus Nijhoff.

Benda-Beckmann, F. v. (1993): Scapegoat and Magic Charm: Law in Development Theory and Practice. In Mark Hobart (ed.) An Anthropological Critique of Development: The Growth of Ignorance. London, Routledge, pp 116134

Benda-Beckmann, F. v. (1994): Rechtspluralismus: Analytische Begriffsbildung oder PolitischIdeologisches Programm? In: Zeitschrift für Ethnologie, 119, 1-16.

Benda-Beckmann, F. v. (2001): State, Religion and Legal Pluralism: Changing Constellations in West Sumatra (Minangkabau) and Comparative Issues (19-th Working Paper). Halle/Saale: Max Planck Institute for Social Anthropology.

Benda-Beckmann, F.v. and K. v. Benda-Beckmann (2007): Gesellschaftliche Wirkung von Recht: Rechtsethnologische Perspektiven. Berlin: Dietrich Reimer Verlag.

Dupret, B. Berger, M. et al (1999): Legal Pluralism in the Arab World. The Hague: Kluwer Law International.

Huda, Y. (2003): Islamic Law versus Adat: Debates about Inheritance Law and the Rise of Capitalism in Minangkabau (MA Thesis). Leiden: University of Leiden.

Manan, I. (1984): A Traditional Elite in Continuity and Change: the Chiefs of the Matrilineal Lineages of the Minangkabau of West Sumatra, Indonesia ( A Dissertation). Michigan: University Microfilms International.

Sangguno Dirajo I. Dt. (2003): Curaian Adat Minangkabau. Bukittinggi: Kristal Multimedia.

Syarifuddin, A. (1984): Pelaksanaan Hukum Kewarisan Islam dalam Lingkungan Adat Minangkabau. Jakarta: Gunung Agung.

http://www.eth.mpg.de/dynamic-index.html?http:// www.eth.mpg.de/people/fbenda/project.html 